\title{
USULAN PENYEIMBANGAN LINTASAN PRODUKSI PADA LINE FINAL ASSEMBLING KWH OB91Z GUNA MENINGKATKAN EFISIENSI LINTASAN PRODUK DI PT METBELOSA
}

\author{
Siti Aisyah $^{(1)}$, Mediana ${ }^{(2)}$ \\ 1,2 Jurusan Teknik Dan Manajemen Industri, Sekolah Tinggi Manajemen Industri
}

\begin{abstract}
Smooth production in a manufacturing firm is very important because it will affect the outcome of which is the expected output of the production trajectory balance that existed at the company if it is optimal or not. The objectives to be achieved in this research is balancing production trajectory so that the expected target company can be reached, drink idle time, and improve the efficiency of the production trajectory. At PT METBELOSA there are trajectories that have not been balanced by the production of idle time on the final line for assembling OB91Z 1.606149 minutes, balance delay in assembling the final line OB91Z by $29.75 \%$ and the efficiency in assembling the final line OB91Z of $70.25 \%$, from Data collection on the final assembling line OB91Z also note that the company can not achieve the expected production targets every day as many as $1500 \mathrm{kwh}$ meter OB91Z type. Therefore the company needs to make improvements in the balancing path to reach their intended target in the final assembling line OB91Z. The method used is a heuristic method MALB (Mansoor Aided Line Balancing) and heuristic methods COMSOAL (Computer Method for Sequencing Operations for Assembly Lines). The data used is data on the production process of assembling the final line OB91Z and the amount of labor in assembling the final line OB91Z. After making improvements by using heuristic methods MALB (Mansoor Aided Line Balancing) then the balance delay becomes $14.62 \%$ and $85.38 \%$ effeciency be.
\end{abstract}

Keywords: Line Of Balancing, MALB, COMSOAL, Efficiency, Balance Delay, Work Stations

\section{PENDAHULUAN}

Pada era global sekarang ini, perusahaan-perusahaan industri di Indonesia berusaha untuk melakukan tindakan-tindakan yang membangun sistem perusahaan agar dapat bersaing dengan perusahaanperusahaan lain. Produktifitas yang sangat tinggi akan dapat dicapai dengan pengaturan aliran produksi yang seefisien mungkin.

Salah satu cara agar tercapainya hal tersebut adalah dengan menggunakan atau menerapkan keseimbangan lintasan (line balancing). Proses keseimbangan lintasan bertujuan untuk meningkatkan efisiensi waktu tiap stasiun kerja dan meminimalkan waktu menunggu. Lintasan produksi yang tidak seimbang dapat dilihat dari gejala menganggurnya beberapa operator atau peralatan di satu stasiun kerja dan sibuknya operator atau peralatan di stasiun kerja lain. Disamping itu juga terdapat penumpukan barang antar stasiun kerja yang satu dengan stasiun kerja yang lain.
Ketidakseimbangan lintasan juga dapat terjadi dikarnakan penempatan stasiun kerja yang tidak tepat, sehingga mengakibatkan proses aliran produksi terhambat, selain itu juga penempatan stasiun kerja yang kurang tepat akan mengakibatkan pemborosan pemakaian lantai produksi.

PT METBELOSA merupakan perusahaan yang memproduksi Kwh meter tipe OB91Z. Didalam pencapaian produksi khususnya pada line final assembling OB91Z sering mengalami hambatan pada keseimbangan beban kerja antar stasiun kerja yang satu dengan stasiun kerja yang lainnya, sehingga mengakibatkan terjadinya bottleneck dibeberapa stasiun kerja. Ketidakseimbangan beban kerja tersebut mengakibatkan target produksi pada line final assembling OB91Z tidak tercapai. Dengan tidak tercapainya target produksi pada line final assembling OB91Z maka perusahaan harus mengadakan lembur pada line tersebut. 


\section{COMPANY PROFILE}

\begin{tabular}{|c|c|}
\hline Name & : PT METBELOSA \\
\hline Established & : February $24^{\text {th }}, 1982$ \\
\hline Address & $\begin{array}{l}\text { : Jl. Taruna No.1 Pulogadung } \\
\text { Jakarta Timur 13068, PO Box } \\
6825 / \text { Jat.Jr }\end{array}$ \\
\hline Phone & : (021) 4714991 (hunting) \\
\hline Fax & : \\
\hline E-mail & $: \frac{\text { supardjis@metbelosa.co.id }}{\text { metbe07@ indosat.net.id }}$ \\
\hline$U R L$ & : http://www.metbelosa.com \\
\hline Field & : Electrical Energy Meter Industry \\
\hline Pald Up Cap & : US \$ 5 Million \\
\hline Shareholder & $\begin{array}{l}\text { : Osaki Electric Co.,Ltd } 85 \% \\
\text { PT. Krakatau Steel 15\% }\end{array}$ \\
\hline \multirow[t]{2}{*}{ Products } & $\begin{array}{l}\text { Single phase kwh meter } 1.000,000 \\
\text { pcs/year }\end{array}$ \\
\hline & $\begin{array}{l}\text { Three phase kwh meter } 80,000 \\
\text { pcs/year }\end{array}$ \\
\hline Tot employees & : 198 persons \\
\hline ite & $: \pm 18.0000 \mathrm{~m}^{2}$ \\
\hline
\end{tabular}

Pada awalnya PT METBELOSA hanya mampu melaksanakan perakitan terhadap komponenkomponen kwh meter menjadi produk kwh meter. November 1983, PT METBELOSA sudah dapat memproduksi sendiri produk Kwh meter.

\subsection{Keseimbangan Lintasan Rakitan}

Pada saat ini masih banyak praktik line balancing berdasarkan pendekatan tradisional yang hanya mengejar keseimbangan beban setiap stasiun kerja tanpa memperhatikan apakah hal itu akan menciptakan WIP (Work In Process) inventory atau tidak. Patut diketahui bahwa meskipun line balancing mencapai target optimal 100\% (seluruh stasiun kerja memiliki beban kerja yang sama), tetapi apabila average cycle time setiap stasiun kerja itu lebih besar dari tact time, maka hal itu akan menciptakan waktu tunggu yang lama bagi pelanggan.

Sebaliknya, apabila average cycle time dari stasiun kerja lebih kecil daripada tact time, hal itu akan menciptakan inventory yang menumpuk. Setiap pekerjaan line balancing harus tetap memperhatikan nilai tact time sebagai nilai referensi.

- Keseimbangan lintasan atau kesamaan output atau keluaran produk pada urutan lintasan operasi. Jika keluaran disetiap operasi sama, maka didapatkan keseimbangan yang sempurna. Tetapi jika keluaran yang dihasilkan tidak sama, maka output maksimum yang mungkin dicapai untuk lintasan operasi tersebut secara keseluruhan akan dipengaruhi oleh operasi yang lama. Operasi yang terlama tersebut dinamakan "bottleneck".

- Satu sama lain mempunyai waktu penyelesaian atau waktu siklus yang sama atau kira-kira hampir sama, sehingga diharapkan suatu proses penyelesaian produk dari suatu operasi ke operasi berikutnya dapat berjalan dengan kecepatan yang konstan.

\subsection{Melakukan pengukuran Waktu}

Pengukuran waktu adalah pekerjaan mengamati dan mencatat waktu-waktu kerjanya baik setiap elemen ataupun siklus dengan menggunakan alat-alat yang telah disiapkan.

Langkah-langkah dalam pengukuran waktu adalah:

1. Pengukuran pendahuluan

Dalam kegiatan pengukuran yang pertama dilakukan adalah melakukan pengukuran pendahuluan dimana bertujuan untuk mengetahui berapa kali pengukuran harus dilakukan untuk tingkat ketelitian dan keyakinan yang diinginkan.

2. Uji Statistik Data

Setelah pengukuran pendahuluan dilakukan maka dilanjutkan dengan melakukan pengujian keseragaman data dan bila waktu yang didapat telah seragam dan cukup maka tidak diperlukan pengukuran tahap berikutnya.

Langkah-langkah dalam uji keseragaman data adalah sebagai berikut:

a. Mengelompokkan data kedalam subgroupsubgroup

Tabel II.1 Mengelompokkan Data dalam subgroup-subgroup

\begin{tabular}{|c|ccccc|c|}
\hline \multirow{3}{*}{ Subgrup } & \multicolumn{5}{|c|}{ Waktu penyelesaian } & $\begin{array}{c}\text { Rata-rata } \\
\text { Subgroup }\end{array}$ \\
\cline { 2 - 6 } & $\mathrm{X} 1$ & $\mathrm{X} 2$ & $\mathrm{X} 3$ & $\ldots$ & $\mathrm{Xn}$ & $\sum \mathrm{X} 1$ \\
1 & $\mathrm{X} 11$ & $\mathrm{X} 12$ & $\mathrm{X} 13$ & $\ldots$ & $\mathrm{X} 1 \mathrm{n}$ & $\sum \mathrm{X} 2$ \\
2 & $\mathrm{X} 21$ & $\mathrm{X} 22$ & $\mathrm{X} 23$ & $\ldots$ & $\mathrm{X} 2 \mathrm{n}$ & $\sum \mathrm{X} 3$ \\
3 & $\mathrm{X} 31$ & $\mathrm{X} 32$ & $\mathrm{X} 33$ & $\ldots$ & $\mathrm{X} 3 \mathrm{n}$ & $\sum \mathrm{Xn}$ \\
$\mathrm{X}$ & $\mathrm{X}$ & $\mathrm{X}$ & $\mathrm{X}$ & $\ldots$ & $\mathrm{Xki}$ & $\sum \mathrm{Xi}$ \\
\hline
\end{tabular}


b. Menghitung harga rata-rata subgroup

$$
\bar{X}=\sum X n
$$

c. Menghitung harg $\boldsymbol{h}$ rata-rata dari harga rata-rata subgroup

$$
\overline{\bar{X}}=\frac{\sum X_{i}}{n}
$$

d. Menghitung standar deviasi sebenarnya

$$
\sigma=\sqrt{\frac{\sum\left(X_{i}-\bar{X}\right)^{2}}{N-1}}
$$

e. Menghitung standar deviasi dari harga rata-rata subgroup

$$
\sigma x=\frac{\sigma}{\sqrt{n}}
$$

Untuk menentukan batas kontrol atas dan batas kontrol bawah, rumus yang digunakan adalah sebagai berikut:

Untuk tingkat keyakinan 95\%

$$
\begin{aligned}
& B K A=\bar{x}+2 \sigma \\
& B K B=\bar{x}-2 \sigma
\end{aligned}
$$

Dimana:

$$
\overline{\mathrm{x}}=\frac{\sum \mathrm{Xi}}{\mathrm{n}} \sigma=\sqrt{\frac{\sum\left(X_{i}-\bar{X}\right)^{2}}{N-1}}
$$

Keterangan: $\quad \mathrm{x}=$ nilai rata-rata

$$
\begin{aligned}
& \sigma=\text { simpangan baku } \\
& \mathrm{xi}=\text { data waktu } \\
& \mathrm{N}=\text { jumlah data }
\end{aligned}
$$

\section{f. Kecukupan Data}

Setelah menguji keseragaman data maka selanjutnya adalah menentukan pengujian kecukupan data yang ada. Hal ini mengetahui apakah data hasil pengamatan yang telah diambil sudah mencukupi, bila data belum mencukupi maka perlu diadakan pengamatan tambahan untuk mencukupi kekurangan data tersebut. Standar deviasi dari rata-rata masing-masing elemen seperti rumus sebagai berikut:

$$
\sigma_{x}=\frac{\sigma}{\sqrt{N}}
$$

Keterangan: $\sigma \mathrm{x}=$ standar deviasi dari distribusi rata-rata

$\sigma=$ standar deviasi sebenarnya dari pengukuran

$$
\mathrm{N}=\text { jumlah observasi }
$$

Apabila jumlah data $\geq 30$ (populasi), maka rumusnya:

$$
\sigma=\sqrt{\frac{\sum\left(X_{i}-\bar{X}\right)^{2}}{N}}
$$

- Apabila tingkat keyakinan $95 \%$ dan tingkat ketelitian 5\%

$$
\mathrm{N}^{\prime}=\left[\frac{40 \sqrt{\mathrm{N} \sum \mathrm{xi}^{2}-\left(\sum \mathrm{x}_{\mathrm{i}}\right)^{2}}}{\sum \mathrm{xi}_{\mathrm{i}}}\right]^{2}
$$

Jika N' lebih kecil atau sama dengan dari $\mathrm{N}\left(\mathrm{N}^{\prime} \leq\right.$ $\mathrm{N})$ berarti data telah tercukupi, sehingga dapat dilanjutkan dengan mencari waktu baku. Jika $\mathrm{N}^{\prime}$ lebih besar dari $\mathrm{N}\left(\mathrm{N}^{\prime} \geq \mathrm{N}\right)$ berarti data tidak tercukupi, sehingga dilanjutkan dengan melakukan pengukuran sebanyak N'. demikian seterusnya sampai jumlah yang dilakukan.

g. Uji kenormalan data

Uji kenormalan data dilakukan untuk mengetahui apakah data populasi yang diperoleh dari hasil pengukuran dari masing-masing jenis data waktu terdistribusi secara normal atau tidak. Dalam penelitian kali ini penulis menggunakan One Sampel Kolmogorov-Smirnov Test untuk melakukan uji kenormalan data. Melalui hasil uji kenormalan data dengan menggunakan One Sampel Kolmogorov-Smirnov Test tersebut, dapat diketahui apakah data yang didapatkan terdistribusi normal atau tidak. Dan dalam pengujian kenormalan data kali ini diasumsikan bahwa Tingkat Keyakinan 95\% $\left(Z_{95 \%}=1,96\right)$ dan Tingkat ketelitian $(\alpha) 5 \%$.

\section{h. Westinghouse}

Cara Westinghouse mengarahkan penilaian pada 4 faktor. Keempat faktor ini adalah keterampilan, usaha, kondisi kerja dan konsistensi. Untuk keperluan penyesuaian maka dibagi dalam enam kelas yaitu super skill, excellent skill, good skill, average skill, fair skill dan poor skill. Penilaian yang diberikan berdasarkan pengamatan penulis terhadap kinerja operator berdasarkan angkaangka yang diberikan bagi setiap kelas dari faktor-faktor diatas pada tabel II.2 dibawah ini. 
Tabel II.2 Penyesuaian menurut Westinghouse

\begin{tabular}{|c|c|c|c|}
\hline Faktor & Kelas & Lambang & Penyesuaian \\
\hline \multirow[t]{11}{*}{ Ketrampilan } & Superskil & A1 & $+0,15$ \\
\hline & & A2 & $+0,13$ \\
\hline & Excellent & B1 & $+0,11$ \\
\hline & & B2 & $+0,08$ \\
\hline & Good & $\mathrm{C} 1$ & $+0,06$ \\
\hline & & $\mathrm{C} 2$ & $+0,03$ \\
\hline & Average & D & 0,00 \\
\hline & Fair & E1 & $-0,05$ \\
\hline & & E2 & $-0,10$ \\
\hline & Poor & F1 & $-0,16$ \\
\hline & & F2 & $-0,22$ \\
\hline \multirow[t]{11}{*}{ Usaha } & Excessive & A1 & $+0,13$ \\
\hline & & A2 & $+0,12$ \\
\hline & Excelent & B1 & $+0,10$ \\
\hline & & B2 & $+0,08$ \\
\hline & Good & $\mathrm{C} 1$ & $+0,05$ \\
\hline & & $\mathrm{C} 2$ & $+0,02$ \\
\hline & Average & D & 0,00 \\
\hline & Fair & E1 & $-0,04$ \\
\hline & & E2 & $-0,02$ \\
\hline & Poor & F1 & $-0,03$ \\
\hline & & F2 & $-0,07$ \\
\hline \multirow[t]{6}{*}{ Kondisi Kerja } & Ideal & A & $+0,06$ \\
\hline & Excellenty & B & $+0,04$ \\
\hline & Good & $\mathrm{C}$ & $+0,02$ \\
\hline & Average & D & 0,00 \\
\hline & Fair & $\mathrm{E}$ & $-0,03$ \\
\hline & Poor & $\mathrm{F}$ & $-0,07$ \\
\hline \multirow[t]{6}{*}{ Konsistensi } & Perfect & A & $+0,04$ \\
\hline & Excellent & B & $+0,03$ \\
\hline & Good & $\mathrm{C}$ & $+0,01$ \\
\hline & Average & D & 0,00 \\
\hline & Fair & E & $-0,02$ \\
\hline & Poor & F & $-0,04$ \\
\hline
\end{tabular}

i. Kelonggaran untuk Hambatan-Hambatan Tak yang tidak dapat dihindarkan seperti mengobrol Terhindarkan

Dalam melaksanakan pekerjaannya, operator tidak akan lepas dari berbagai hambatan. Ada hambatan 
Tabel II.3 Kelonggaran

\begin{tabular}{|c|c|c|}
\hline \multirow{2}{*}{ Faktor } & \multicolumn{2}{|c|}{ Kelonggaran } \\
\hline & Pria & Wanita \\
\hline \\
\hline \multirow{7}{*}{$\begin{array}{l}\text { 1.Dapat diabaikan } \\
\text { 2.Sangat ringan } \\
\text { 3. Ringan } \\
\text { 4.Sedang } \\
\text { 5.Berat } \\
\text { 6.Sangat berat } \\
\text { 7. Luar biasa berat }\end{array}$} & $0,0-6,0$ & $0,0-6,0$ \\
\hline & $6,0-7,5$ & $6,0-7,5$ \\
\hline & $7,5-12,0$ & $7,5-16,0$ \\
\hline & $12,0-19,0$ & $16,0-30,0$ \\
\hline & $19,0-30,0$ & \\
\hline & $30,0-50,0$ & \\
\hline & & \\
\hline \multirow{5}{*}{$\begin{array}{l}\text { B. Sikap kerja } \\
\text { 1.Duduk } \\
\text { 2.Berdiri diatas dua kaki } \\
\text { 3.Berdiri diatas satu kaki } \\
\text { 4.Berbaring } \\
\text { 5.Membungkuk }\end{array}$} & & \\
\hline & $\frac{0,00-1,0}{1,0-2,5}$ & $\frac{0,00-1,0}{1,0-2,5}$ \\
\hline & $2,5-4,0$ & $2,5-4,0$ \\
\hline & $2,5-4,0$ & $2,5-4,0$ \\
\hline & $4,0-10$ & $4,0-10$ \\
\hline \multirow{6}{*}{$\begin{array}{l}\text { C. Gerakan kerja } \\
\text { 1.Normal } \\
\text { 2.Agak terbatas } \\
\text { 3.Sulit } \\
\text { 4.Pada anggota badan terbatas } \\
\text { 5.Seluruh anggota badan terbatas }\end{array}$} & & \\
\hline & 0 & 0 \\
\hline & $0-5$ & $0-5$ \\
\hline & $0-5$ & $0-5$ \\
\hline & $5-10$ & $5-10$ \\
\hline & $10-15$ & $10-15$ \\
\hline & \multicolumn{2}{|c|}{ Kelonggaran $(\%)$} \\
\hline \multirow{6}{*}{$\begin{array}{l}\text { D. Kelelahan mata } \\
\text { 1.pandangan yang terputus-putus } \\
\text { 2.Pandangan yang hampir terus menerus } \\
\text { 3.Pandangan yang terus menerus } \\
\text { dengan fokus berubah-ubah } \\
\text { 4.Pandangan yang terus menerus dengan fokus tetap }\end{array}$} & Pencahayaan baik & Buruk \\
\hline & $0,0-6,0$ & $0,0-6,0$ \\
\hline & $6,0-7,5$ & $6,0-7,5$ \\
\hline & $7,5-12,0$ & $7,5-16,0$ \\
\hline & & \\
\hline & $19,0-30,0$ & $16,0-30,0$ \\
\hline
\end{tabular}

Menghitung waktu siklus rata-rata:

$$
W s=\frac{\sum X_{i}}{N}
$$

1. Menghitung faktor penyesuaian:

Faktor penyesuaian $=1+p$

2. Menghitung waktu normal:

$\mathrm{Wn}=\mathrm{Ws}$ x penyesuaian

3. Menghitung waktu baku

Waktu baku $=\mathrm{Wn}+(\mathrm{Wn} \times \mathrm{A})$

\subsection{Metode Mansoor Aided Line Balancing (MALB).}

MALB merupakan salah satu teknik heuristic untuk masalah berskala besar yang telah dikomputerisasi. Metode ini merupakan penyempurnaan dari metode
Rank Postional Weight (Helgeson-Birnie) sebagai dasarnya yang diperoleh dari perhitungan manual. Cara penentuan bobot dari precedence diagram dimulai dari proses akhir.

Bobot $(\mathrm{RPW})=$ Waktu proses operasi tersebut + Waktu proses operasi-operasi yang berikutnya

Langkah-langkah metode MALB dengan perhitungan manual:

1. Gambar jaringan Precedence sesuai dengan keadaan yang sebenarnya.

2. Tentukan positional weight (bobot posisi) untuk setiap elemen pekerjaan dari suatu operasi yang memiliki waktu penyelesaian (waktu baku) terpanjang mulai dari awal pekerjaan hingga ke 
akhir elemen pekerjaan yang memiliki waktu penyelesaian (waktu baku) terendah.

3. Urutkan elemen pekerjaan berdasarkan positional weight pada langkah $\mathrm{ke}-2$ di atas. Elemen pekerjaan yang memiliki positional weight tertinggi diurutkan pertama kali.

4. Lanjutkan dengan menempatkan elemen pekerjaan yang memiliki positional weight tertinggi pada variabel penampung, lalu hitung waktu senggangnya. Bila sesuai dengan prohibit table, tempatkan pada variabel penampung.

5. Bila waktu proses lebih besar dari cycle time, pindahkan proses terakhir ke variabel penampung berikutnya dan hitung waktu senggangnya.

6. Ulangi langkah ke-4 dan ke-5 diatas sampai seluruh elemen pekerjaan sudah ditempatkan.

\subsection{Metode COMSOAL}

COMSOAL (Computer Method for Sequencing Operation for Assembly Lines) metode dasar COMSOAL didasarkan pada berkembangnya sejumlah besar pemecahan yang layak bagi keseimbangan lini dengan metode 'biased sampling'. Pemecahan alternatif untuk masalah keseimbangan lini tertentu kemudian didasarkan pada pemecahan terbaik yang dihasilkan. Metode COMSOAL ini dilakukan dengan cara pembobotan untuk memilih tugas yang sesuai dengan precedence diagram melalui hasil perkalian lima bobot dasar sebagai berikut:

1. Bobotlah tugas yang sesuai dengan proporsi waktu tugas (a). Pengaruh pembobotan ini adalah memberikan tugas yang lama peluang lebih tinggi untuk dipilih ketimbang tugas yang singkat.

2. Bobotlah tugas yang sesuai dengan $1 / \mathrm{X}$, dimana $\mathrm{X}$ adalah sama dengan jumlah total tugas yang belum terpilih ke dalam stasiun dikurangi 1, dikurangi dengan jumlah semua tugas yang mengikuti tugas yang sedang dipertimbangkan. Pengaruh dari aturan dua ini adalah memberikan kepada tugas-tugas yang mempunyai banyak tugas yang mengikutinya peluang lebih besar untuk terpilih dibandingkan dengan tugas yang mempunyai sedikit tugas yang mengikutinya.

3. Bobot tugas yang sesuai dengan jumlah total semua tugas yang mengikutinya ditambah 1 . Akibat dari aturan ini adalah mendahulukan tugas yang bila terpilih akan digantikan dan dengan demikian memperluas daftar yang tersedia.

4. Bobotlah tugas yang sesuai dengan waktu tugas tersebut dan waktu semua tugas yang mengikutinya. Hasil dari aturan ini adalah menggabungkan manfaat satu dan tiga dengan memilih tugas yang lama secara dini pada tiaptiap stasiun di keselurahan urutan satu dengan mendahulukan tugas yang walaupun singkat tetapi cenderung akan memeperluas daftar tersedia.

5. Bobotlah tugas yang sesuai dengan jumlah total tugas yang mengikutinya ditambah 1 . dibagi dengan jumlah tingkat (level) yang ditempati oleh tugas-tugas yang mengikutinya. Pengaruh dari pembobotan ini adalah memberikan tugas yang memiliki rantai terpanjang untuk dipilih.

6. Hitunglah rasio yang diperoleh dari perkalian faktor-faktor di atas sehingga elemen yang memiliki rasio terbesar dapat masuk kedalam pembagian stasiun. Namun suatu elemen dapat masuk ke dalam stasiun bila elemen-elemen yang mendahuluinya sudah lebih dahulu ditugaskan dan waktu siklus yang tersedia masih mencukupi.

Berikut ini merupakan tahapan perhitungan dengan metode COMSOAL yaitu:

1. Daftarkan elemen kerja (i) pada iterasinya dimana elemen kerja tersebut tidak melanggar aturan precedence. Untuk iterasi 1. elemen kerja yang masuk dalam iterasi ini adalah elemen yang tergolong elemen kerja bebas atau elemen kerja yang tidak memiliki precedence.

2. Kemudian, hitung jumlah elemen yang belum ditugaskan untuk membuat produk. Dimana rumus tersebut:

Jumlah elemen yang belum ditugaskan $=$ $\sum \mathrm{n}+1-\mathrm{i}$

Dimana $\mathrm{n}=$ banyaknya elemen kerja dalam membuat sebuah produk $\mathrm{i}=$ iterasi ke-i

3. Hitung jumlah elemen yang mengikuti dari elemen kerja yang didaftarkan pada iterasi.

4. Hitung nilai bobot $\mathrm{x}$ dengan rumus:

$$
\mathrm{x}=\left[\left(\sum \mathrm{n}+1-\mathrm{i}\right)-\mathrm{i}\right]-\text { jumlah elemen yang }
$$
mengikuti

5. Hitung nilai bobot $1 / x$ untuk setiap elemen kerja.

6. Hitung nilai bobot $\mathrm{b}$ untuk setiap elemen kerja pada tiap iterasinya dengan rumus: $b=$ jumlah elemen yang mengikuti +1

7. Hitung nilai bobot waktu untuk tiap elemen kerja. Dimana nilai bobot ini tergantung dari jumlah elemen kerja yang mengikuti. Bobot waktu (RPW) merupakan jumlah waktu elemen kerja tersebut ditambah dengan jumlah waktu elemen kerja yang mengikutinya.

8. Hitung nilai RA atau nilai pengelompokan elemen kerja berdasarkan precedence diagram COMSOAL yang dirata kanan. 
9. Hitung nilai d pada setiap elemen kerja pada iterasinya dengan rumus: $d=b / R A$

Rasio $=$ waktu elemen $\mathrm{x}(1 / \mathrm{x}) \times \mathrm{x} b$ bobot

10. Setelah nilai bobot telah dihitung semua, selanjutnya hitung nilai rasio elemen kerja dengan rumus:

\section{PENGOLAHAN DATA}

Tabel IV.1 Uraian elemen kerja pada Line Final Assembling OB91Z

\begin{tabular}{|c|c|c|}
\hline $\begin{array}{c}\text { NO ELEMEN } \\
\text { KERJA }\end{array}$ & URAIAN ELEMEN KERJA & NAMA MESIN \\
\hline & Terminal Blok & \\
\hline 1. & Memasang terminal A kanan & No machine \\
\hline 2. & Memasang terminal A kiri & No machine \\
\hline 3. & Memasang pieces & No machine \\
\hline 4. & Memasang terminal B & No machine \\
\hline 5. & Memasang zig pada terminal blok & No machine \\
\hline 6. & Memasang screw $4 \times 8$ ke dalam lubang terminal blok & No machine \\
\hline 7. & Memasang screw 3x6 ke dalam lubang terminal blok & No machine \\
\hline 8. & Men-Zig semua scew yang sudah terpasang & Machine Zig \\
\hline 9. & Membersihkan terminal bLok dengan pembersih angin & Penyemprot angin \\
\hline 10. & Memasang gasket & No machine \\
\hline \multirow[t]{2}{*}{11.} & Memasang pieces ke f $\mathrm{x}$ Terminal blok & No machine \\
\hline & Assembly Base & \\
\hline 12. & Mengambil base & No machine \\
\hline 13. & Memasang fx Terminal blok ke base & No machine \\
\hline 14. & Memasang screw earth Terminal blok pada base & Machine Zig \\
\hline 15. & Memasang short bar Terminal blok pada base & Machine Zig \\
\hline \multirow[t]{2}{*}{16.} & Screw for fx Terminal blok & Machine Zig \\
\hline & Assembly DIV Elemen & \\
\hline 17. & Pemasangan DIV elemen & No machine \\
\hline 18. & Pemasangan elemen kabel Voltage & No machine \\
\hline 19. & Pemasangan elemen kabel current & No machine \\
\hline 20. & Mengencangkan elemen kabel Voltage & Machine Zig \\
\hline 21. & Mengencangkan elemen kabel current & Machine Zig \\
\hline 22. & Merapihkan DIV elemen & No machine \\
\hline 23. & Memasang screw current & Machine Zig \\
\hline 24. & Memasang Jumper & Machine Zig \\
\hline 25. & Memasang screw main frame ms kiri & Machine Zig \\
\hline 26. & Memasang screw main frame ms kanan & Machine Zig \\
\hline \multirow[t]{2}{*}{27.} & Memasang screw IL Plate m4 & Machine Zig \\
\hline & Assembly Rotor & \\
\hline 28. & Memasang Rotor ke Gap elemen & No machine \\
\hline 29. & Memasang lower ke main frame & No machine \\
\hline 30. & Memasang rotor bearing ass & No machine \\
\hline
\end{tabular}

\begin{tabular}{|l|l|c|}
\hline 31. & Mengencangkan rotor pada upper & Air drive \\
\hline 32. & Memasang lower pada rotor & Air drive \\
\hline
\end{tabular}




\begin{tabular}{|c|c|c|}
\hline 33. & Mengencangkan lower pada rotor & Tarque \\
\hline \multirow[t]{2}{*}{34.} & Setel Rotor & No machine \\
\hline & Assembly Brake Magnet & \\
\hline 35. & Memasang Brake magnet & No machine \\
\hline 36. & Memasang screw Brake magnet kanan & Machine Zig \\
\hline 37. & Memasang screw Brake magnet kiri & Machine Zig \\
\hline 38. & Menstell screw brake magnet & Obeng \\
\hline \multirow[t]{2}{*}{39.} & Pengurangan kadar magnet & Obeng \\
\hline & Penstellan Magnet 1 & \\
\hline 40. & Memasang kwh pada mesin whm automatic adj & No machine \\
\hline 41. & Pengurangan kadar magnet & Obeng \\
\hline \multirow[t]{2}{*}{42.} & Pengadjustan brake magnet (full load) & Whm automatic Adj \\
\hline & Penstellan Magnet 2 & \\
\hline 43. & Memasang kwh pada mesin LL adj & No machine \\
\hline 44. & Mensensor rotor & Machine LL adj \\
\hline \multirow[t]{2}{*}{45.} & Adj light load & Obeng \\
\hline & Assembly register & \\
\hline 46. & Memasang kwh pada papan kerja & No machine \\
\hline 47. & Memasang register pada zig & No machine \\
\hline 48. & Zig screw kanan pada kwh & Machine Zig \\
\hline 49. & Zig screw kiri pada kwh & Machine Zig \\
\hline 50. & Membersihan kwh yg sudah jadi & Penyemprot angin \\
\hline
\end{tabular}

Jaringan kerja adalah jaringan yang menggambarkan urutan dari suatu pekerjaan. Sehingga dengan melihat jaringan kerja dapat diketahui pekerjaan pendahulu atau pekerjaan yang mengikutinya. Berikut adalah gambar dari jaringan kerja line final assembling OB91Z 

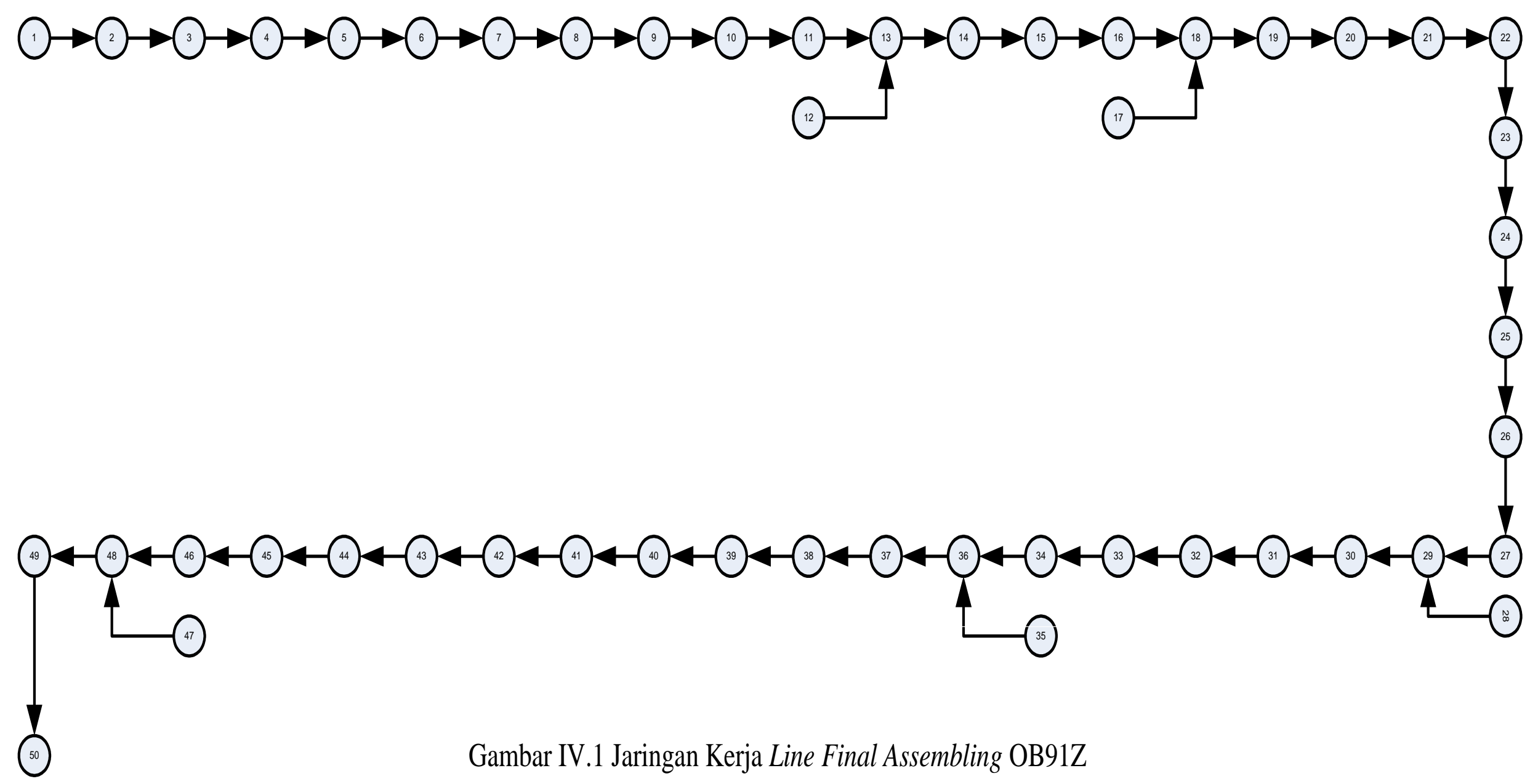


\subsection{Perhitungan dengan MALB}

Tabel 3.1 : Perhitungan dengan MALB

\begin{tabular}{|c|c|c|c|c|c|}
\hline Stasiun kerja & Elemen kerja & Rasio minimum & $\begin{array}{c}\text { Total waktu stasiun } \\
\text { (menit) }\end{array}$ & Efisiensi stasiun kerja & $\begin{array}{c}\text { Waktu menganggur } \\
\text { (menit) }\end{array}$ \\
\hline \multirow{5}{*}{ Stasiun 1} & 1 & 0,054499 & \multirow{5}{*}{0,271390} & \multirow{5}{*}{$85,51 \%$} & \multirow{5}{*}{0,045970} \\
\hline & 2 & 0,053711 & & & \\
\hline & 3 & 0,053306 & & & \\
\hline & 4 & 0,054105 & & & \\
\hline & 5 & 0,055775 & & & \\
\hline \multirow{2}{*}{ Stasiun 2} & 6 & $\mathbf{0 , 1 0 5 3 9 7}$ & \multirow{2}{*}{0,177440} & \multirow{2}{*}{$55,91 \%$} & \multirow{2}{*}{0,139918} \\
\hline & 7 & 0,072051 & & & \\
\hline \multirow{5}{*}{ Stasiun 3} & 8 & 0,164668 & \multirow{5}{*}{0.311450} & \multirow{5}{*}{$98,13 \%$} & \multirow{5}{*}{0,005907} \\
\hline & 9 & 0,036564 & & & \\
\hline & 10 & 0,036564 & & & \\
\hline & 12 & 0,037099 & & & \\
\hline & 11 & 0,036564 & & & \\
\hline \multirow{3}{*}{ Stasiun 4} & 13 & 0,037099 & \multirow{3}{*}{0,244010} & \multirow{3}{*}{$76,88 \%$} & \multirow{3}{*}{$\mathbf{0 , 0 7 3 3 5 2}$} \\
\hline & 14 & 0,081988 & & & \\
\hline & 15 & 0,124927 & & & \\
\hline \multirow{3}{*}{ Stasiun 5} & 17 & $\mathbf{0 , 1 1 9 0 1 7}$ & \multirow{3}{*}{0,277480} & \multirow{3}{*}{$87,43 \%$} & \\
\hline & 16 & 0,037099 & & & \\
\hline & 18 & 0,121369 & & & 0,039881 \\
\hline & 19 & 0,130056 & & & \\
\hline & 20 & 0,041469 & & & \\
\hline Stasiun 6 & 21 & 0,050131 & 0,256870 & $80,93 \%$ & 0,060490 \\
\hline & 22 & $\mathbf{0 , 0 3 5 2 2 0}$ & & & \\
\hline & 23 & 0,091667 & & & \\
\hline Stasiun 7 & 24 & 0,090545 & 0,271710 & $85,61 \%$ & 0,045656 \\
\hline & 25 & 0,089498 & & & \\
\hline & 26 & 0,068983 & & & \\
\hline & 27 & 0,096207 & & & \\
\hline Stasiun 8 & 28 & 0,039363 & 0,299940 & $94,50 \%$ & 0,017426 \\
\hline & 29 & 0,056029 & & & \\
\hline & 30 & 0,039363 & & & \\
\hline & 31 & $\mathbf{0 , 0 3 9 3 6 3}$ & & & \\
\hline & 32 & 0,039363 & & & \\
\hline Stasiun 9 & 33 & 0,039363 & 0,277866 & $87,55 \%$ & 0,039500 \\
\hline & 34 & 0,107468 & & & \\
\hline & 35 & 0,052309 & & & \\
\hline & 36 & 0,089036 & & & \\
\hline Staiun 10 & 37 & $\mathbf{0 , 0 7 1 4 3 9}$ & 0,160475 & $50,56 \%$ & 0,156891 \\
\hline & 38 & 0,168672 & & & \\
\hline & 39 & 0,037543 & & & \\
\hline Stasiun 11 & 40 & 0,038961 & 0,284137 & $89,52 \%$ & 0,033229 \\
\hline & 41 & 0,038961 & & & \\
\hline Stasiun 12 & 42 & 0.307756 & $\mathbf{0 , 3 0 7 7 5 6}$ & $96,97 \%$ & 0,009610 \\
\hline & 43 & 0,037765 & & & \\
\hline Stasiun 13 & 44 & 0,179310 & 0,317366 & $100 \%$ & 0 \\
\hline & 45 & 0,100291 & & & \\
\hline & 47 & 0,073736 & & & \\
\hline & 46 & 0,055200 & & & \\
\hline Stasiun 14 & 48 & 0,068891 & $0,335418 / 2$ & $52,85 \%$ & 0,149657 \\
\hline & 49 & 0,068891 & & & \\
\hline & 50 & 0,068700 & & & \\
\hline Efis & $i$ Lini $=\frac{\sum_{i=1}^{N}}{(m)}$ & $x 100 \%$ & & $d=\frac{(M)(C)-\sum_{i=1}^{N} t i}{M \times C}$ & \\
\hline Effis & $i$ Lini $=\frac{3,7}{(14)(0}$ & $\frac{3351}{17366)} \times 100 \%$ & & $d=\frac{(14)(0,317366)}{(14)(0,317}$ & $3351 \times 100 \%$ \\
\hline & $=85,3$ & & & $\begin{array}{l}d=14,62 \% \\
\text { Balance delay }\end{array}$ & $\%$ - Efisiensi Lini \\
\hline
\end{tabular}




$$
\begin{aligned}
& =100 \%-85,38 \% \\
& =14,62 \%
\end{aligned}
$$

$$
\begin{aligned}
\text { Kapasitas produksi } & =\frac{\text { Jam kerja menit/hari }}{\text { tact time menit/unit }} \\
& =\frac{8 \mathrm{jam} \times 60 \mathrm{menit} / \mathrm{hari}}{0,31736 \mathrm{menit} / \mathrm{unit}} \\
& =1.512 \mathrm{unit} / \mathrm{hari}
\end{aligned}
$$

Dari perhitungan diatas dapat dilihat bahwa target produksi perusahaan adalah 1.500 unit/hari dan dengan dilakukan penyeimbangan lini dengan metode MALB maka output produksi menjadi 1.512 unit/hari. Dari perhitungan MALB diatas maka stasiun kerja menjadi 15 stasiun. Namun penulis memberikan saran kepada perusahaan untuk tidak menambah stasiun kerja melainkan hanya menambah tenaga kerja sebanyak 1 orang yang akan ditempatkan pada stasiun 14, sehingga elemen kerja 50 masuk ke dalam stasiun kerja 14, dengan begitu perusahaan tidak perlu menambah lantai produksi line final assembling OB91Z. Karna pada stasiun kerja 14 ditambahkan 1 orang tenaga kerja maka pada perhitungan total waktu stasiun 14 akan dibagi 2.

\subsection{Perhitungan Effisiensi Lini Dengan}

Menggunakan Metode COMSOAL

Efisiensi Lini $=\frac{\sum_{i=1}^{N} t i}{(m)(c)} \times 100 \%$

Effisiensi Lini $=\frac{3,793351}{(14)(0,31767)} \times 100 \%$

$$
=85,30 \%
$$

$$
d=\frac{(M)(C)-\sum_{i=1}^{N} t i}{M x C} \times 100 \%
$$

$$
\begin{aligned}
& d=\frac{(14)(0,31767)-3,793351}{(14)(0,31767)} \times 100 \% \\
& d=14,70 \% \\
& \text { Balance delay }=100 \% \text { - Efisiensi Lini } \\
& =100 \%-85,30 \% \\
& =14,70 \%
\end{aligned}
$$

$$
\begin{aligned}
\text { Kapasitas produksi } & =\frac{\text { Jam kerja menit/hari }}{\text { tact time menit/unit }} \\
& =\frac{8 \mathrm{jam} \times 60 \mathrm{menit} / \mathrm{hari}}{0,31767 \mathrm{menit} / \mathrm{unit}} \\
& =1.511 \mathrm{unit} / \mathrm{hari}
\end{aligned}
$$

Dari perhitungan diatas dapat dilihat bahwa target produksi perusahaan adalah 1.500 unit/hari dan dengan dilakukan penyeimbangan lini dengan metode COMSOAL maka hasil produksi menjadi 1.511 unit/hari. Dari perhitungan COMSOAL diatas maka stasiun kerja seharusnya menjadi 15 stasiun. Namun penulis memberikan saran kepada perusahaan untuk tidak menambah stasiun kerja melainkan hanya menambah tenaga kerja sebanyak 1 orang yang akan ditempatkan pada stasiun 14 
Tabel 3.2: Metode Comsoal

\begin{tabular}{|c|c|c|c|c|c|}
\hline Stasiun kerja & $\begin{array}{l}\text { Elemen } \\
\text { kerja }\end{array}$ & $\begin{array}{c}\text { Rasio } \\
\text { minimum } \\
\text { (Menit) }\end{array}$ & $\begin{array}{l}\text { Total waktu } \\
\text { stasiun kerja } \\
\text { (Menit) }\end{array}$ & $\begin{array}{c}\text { Efisiensi stasiun } \\
\text { kerja } \\
(\%)\end{array}$ & $\begin{array}{c}\text { Waktu } \\
\text { menganggur } \\
\text { (Menit) }\end{array}$ \\
\hline \multirow{4}{*}{ Stasiun 1} & 1 & 0,054499 & \multirow{4}{*}{0,215620} & \multirow{4}{*}{$67,88 \%$} & \multirow{4}{*}{0,102050} \\
\hline & 2 & 0,053711 & & & \\
\hline & 3 & 0,053306 & & & \\
\hline & 4 & 0,054105 & & & \\
\hline \multirow[t]{2}{*}{ Stasiun 2} & 6 & 0,105397 & \multirow[t]{2}{*}{0,161170} & \multirow[t]{2}{*}{$50,74 \%$} & \multirow[t]{2}{*}{0,156500} \\
\hline & 5 & 0,055775 & & & \\
\hline \multirow{4}{*}{ Stasiun 3} & 8 & 0,164668 & \multirow{4}{*}{0,309840} & \multirow{4}{*}{$97,54 \%$} & \multirow{4}{*}{0,007830} \\
\hline & 7 & 0,072051 & & & \\
\hline & 9 & 0,036564 & & & \\
\hline & 10 & 0,036564 & & & \\
\hline \multirow{5}{*}{ Stasiun 4} & 12 & 0,037099 & \multirow{5}{*}{0,317670} & \multirow{5}{*}{$100 \%$} & \multirow{5}{*}{$\mathbf{0}$} \\
\hline & 11 & 0,036564 & & & \\
\hline & 14 & 0,081988 & & & \\
\hline & 15 & 0,124927 & & & \\
\hline & 13 & 0,037099 & & & \\
\hline \multirow[t]{2}{*}{ Stasiun 5} & 17 & 0,119017 & \multirow[t]{2}{*}{0,240380} & \multirow[t]{2}{*}{$75,67 \%$} & \multirow[t]{2}{*}{0,077290} \\
\hline & 18 & 0,121369 & & & \\
\hline \multirow{4}{*}{ Stasiun 6} & 19 & 0,130056 & & & \\
\hline & 16 & 0,037099 & 0,258750 & $81,45 \%$ & 0,058920 \\
\hline & 20 & 0,041469 & & & \\
\hline & 21 & 0,050131 & & & \\
\hline & 23 & 0,091667 & & & \\
\hline Stasiun 7 & 24 & 0,090545 & 0,306930 & $96,6 \%$ & 0,010740 \\
\hline & 22 & 0,035220 & & & \\
\hline & 25 & 0,089498 & & & \\
\hline & 26 & 0,068983 & & & \\
\hline & 27 & 0,096207 & & & \\
\hline Stasiun 8 & 28 & 0,039363 & 0,299940 & $94,42 \%$ & 0,017730 \\
\hline & 29 & 0,056029 & & & \\
\hline & 30 & 0,039363 & & & \\
\hline & 31 & 0,039363 & & & \\
\hline & 32 & 0,039363 & & & \\
\hline Stasiun 9 & 34 & 0,107468 & 0,277860 & $87,47 \%$ & 0,039810 \\
\hline & 33 & 0,039363 & & & \\
\hline & 35 & 0,052309 & & & \\
\hline Stasiun 10 & 36 & 0,089036 & 0,257700 & $81,12 \%$ & 0,059970 \\
\hline & 38 & 0,168672 & & & \\
\hline & 37 & $\mathbf{0 , 0 7 1 4 3 9}$ & & & \\
\hline Stasiun 11 & 39 & 0,037543 & 0,147940 & $46,57 \%$ & 0,169730 \\
\hline & 40 & 0,038961 & & & \\
\hline Stasiun 12 & 42 & 0.307756 & 0,307750 & $96,88 \%$ & 0,009920 \\
\hline & 41 & 0,038961 & & & \\
\hline Stasiun 13 & 44 & $\mathbf{0 , 1 7 9 3 1 0}$ & 0,256030 & $80,60 \%$ & 0,061640 \\
\hline & 43 & 0,037765 & & & \\
\hline & 45 & 0,100291 & & & \\
\hline & 47 & 0,073736 & & & \\
\hline Stasiun 14 & 46 & 0,055200 & $0,435709 / 2$ & $68,57 \%$ & 0,099816 \\
\hline & 48 & 0,068891 & & & \\
\hline & 49 & 0,068891 & & & \\
\hline & 50 & 0,068700 & & & \\
\hline
\end{tabular}




\section{KESIMPULAN}

Dari pengolahan data diatas dapat ditarik kesimpulan sebagai berikut:

a. Dari perhitungan COMSOAL dilihat bahwa target produksi perusahaan adalah 1.500 unit/hari dan dengan dilakukan penyeimbangan lini dengan metode COMSOAL maka hasil produksi menjadi 1.511 unit/hari. Stasiun kerja seharusnya menjadi 15 stasiun. Namun penulis memberikan saran kepada perusahaan untuk tidak menambah stasiun kerja melainkan hanya menambah tenaga kerja sebanyak 1 orang yang akan ditempatkan pada stasiun 14 .

b. Dari perhitungan MALB target produksi perusahaan adalah 1.500 unit/hari dan dengan dilakukan penyeimbangan lini maka output produksi menjadi 1.512 unit/hari. Stasiun kerja menjadi 15 stasiun. Namun penulis memberikan saran kepada perusahaan untuk tidak menambah stasiun kerja melainkan hanya menambah tenaga kerja sebanyak 1 orang yang akan ditempatkan pada stasiun 14, sehingga elemen kerja 50 masuk ke dalam stasiun kerja 14, dengan begitu perusahaan tidak perlu menambah lantai produksi line final assembling OB91Z. Karna pada stasiun kerja 14 ditambahkan 1 orang tenaga kerja maka pada perhitungan total waktu stasiun 14 akan dibagi 2

\section{PUSTAKA}

1. Apple, James, M. Tataletak pabrik dan pemindahan bahan, ITB, Bandung. 1990

2. Buffa, Elwoods. Manajemen produksi. Erlangga. Jakarta. 1997

3. Barnes, Ralph, M. Motion and time study designed measurement of work. John wiley. New jerse. 1980

4. Gaspersz, Vincent. Produktion Planning and Inventory control, Gramedia Pustaka Utama, Jakarta.1998

5. Gaspersz, Vincent. Lean Six Sigma, Gramedia Pustaka Utama, Jakarta. 2007

6. Iftikar, Sutalaksana, Z. Teknik tata Cara Kerja, ITB, Bandung. 1979
7. Suhendi, Edi. Mengelola data dengan SPSS 16.0 untuk peneliti pemula. Yrama Widya, Bandung. 2009

8. Wignjosoebroto, Sritomo. Pengantar teknik dan manajemen industri, Guna widya, Surabaya. 2006

9. Wignjosoebroto, Sritomo. Ergonomi studi gerak dan waktu, Guna widya, Surabaya. 2008 